\title{
Faktor-Faktor Yang Mempengaruhi Volatilitas Harga Saham Perusahaan Manufaktur
}

\author{
Linda Santioso, Yosevin Gloria Angesti \\ Faculty of Economics, Tarumanagara University \\ Email: linda.santioso@gmail.com and Yosevin.125150290@stu.untar.com
}

\begin{abstract}
Abstrct: The purpose of this study is to find out and analyze the influence of dividend policy, earning volatility, debt policy, growth asset and earning per share. The research method used was purposive sampling with a total sample of 35 manufacturing companies listed on the Indonesia Stock Exchange (IDX). This research was conducted using years of observation, namely 2015-2017. The type of data used is secondary data. Data is obtained from financial statements taken from www.idx.com. Data analysis method used is descriptive statistical test,multicollinearity test,f test, $t$ test and test coefficient of determination. Testing the hypothesis in this study uses the t test. The results of the study show that the dividend policy, earning volatility, debt policy and growth asset do not have a significant effect on share price volatility, while the earning per share has a significant negative effect on share price volatility.
\end{abstract}

Keywords: Share Price Volatility, Dividend Policy, Earning Volatility, Debt Policy, Growth Asset, Earning Per Share.

Abstrak: Tujuan dari penelitian ini adalah untuk mengetahui dan menganalisis pengaruh kebijakan dividen, volatilitas pendapatan, kebijakan utang, aset pertumbuhan, dan pendapatan per saham. Metode penelitian yang digunakan adalah purposive sampling dengan jumlah sampel sebanyak 35 perusahaan manufaktur yang terdaftar di Bursa Efek Indonesia (BEI). Penelitian ini dilakukan dengan menggunakan tahun pengamatan, yaitu 2015-2017. Jenis data yang digunakan adalah data sekunder. Data diperoleh dari laporan keuangan yang diambil dari www.idx.com. Metode analisis data yang digunakan adalah uji statistik deskriptif, uji multikolinieritas, uji f, uji t dan uji koefisien determinasi. Pengujian hipotesis dalam penelitian ini menggunakan uji t. Hasil penelitian menunjukkan bahwa kebijakan dividen, volatilitas laba, kebijakan utang dan aset pertumbuhan tidak memiliki pengaruh yang signifikan terhadap volatilitas harga saham, sedangkan laba per saham memiliki pengaruh negatif yang signifikan terhadap volatilitas harga saham.

Kata kunci: Volatilitas Harga Saham, Kebijakan Dividen, Volatilitas Produktif, Kebijakan Utang, Aset Pertumbuhan, Produktif Per Saham.

\section{PENDAHULUAN}

Harga saham merupakan salah satu indikator keberhasilan perusahaan dan sangat dipengaruhi oleh permintaan dan penawaran dari para investor.Harga saham yang cenderung stabil akan membuat para investor lebih tertarik karena tingkat resiko yang dimiliki lebih sedikit dan memang tujuan para investor adalah berinvestasi atau mencari keuntungan. Jika harga saham tidak stabil akan membuat investor tidak memiliki 
kepercayaan untuk berinvestasi. Di Indonesia sendiri, Saat ini harga saham dari seluruh perusahaan di pasar saham masih belum stabil.

Hal ini dibuktikan dari perusahaan-perusahaan yang terdaftar di LQ 45 yang tidak pernah konsisten.Bahkan pada April 2018 lalu, ditemukan bahwa hanya 1 perusahaan yang masih bisa bertahan dari peringkat 10 besar perusahaan di LQ 45.Hal ini menunjukkan bahwa memang harga saham di Indonesia masih jauh dari stabil.

Tentunya dengan harga saham yang tidak stabil, berkaitan dengan teori dalam ilmu akuntansi, yaitu teori signalling. Menurut (Brigham dan Hauston, 2011) isyarat atau signal adalah suatu tindakan yang diambil perusahaan untuk memberi petunjuk bagi investor tentang bagaimana manajemen memandang prospek perusahaan. Sinyal disini dapat dimaksudkan dengan harga saham. Jika harga saham tidak stabil secara terus menerus, hal ini tentunya menjadi signal negatif kepada pasar dan membuat pasar akan kehilangan gairah untuk membeli saham di index Indonesia.

Keadaan naik atau turun dari harga saham dalam jangka waktu tertentu disebut juga volatilitas harga saham. Volatilitas harga saham adalah keadaan dimana harga saham menyimpang (keatas/kebawah) dalam index dari rata-rata. Yang dimaksud disini adalah tingkat volatilitas tinggi dinyatakan dalam naik turunnya grafik sebuah harga saham. Tentunya, banyak faktor yang dapat menyebabkan naik atau turunnya harga saham ini sendiri, dimana dalam penelitian ini, beberapa faktor yang diteliti meliputi dividend policy, earnings volatility, kebijakan hutang, asset growth dan earnings per share.

(Hooi et al., 2015) menjelaskan bahwa dividend policy merupakan hasil persentase dari keuntungan perlembar saham dibagi dengan harga pasar perlembar saham yang diterima perusahaan. Tingginya suatu dividend policy menunjukkan bahwa suatu pasar modal dalam keadaan undervalued, yaitu jika harga pasar saham lebih kecil dari nilai wajarnya, maka saham tesebut harus dibeli dan ditahan sementara (buy and hold) dengan tujuan untuk memperoleh capital gain jika kemudian harganya kembali naik. Dividend policy diduga berpengaruh negatifterhadap volatilitas harga saham, dikarenakan jika dividend yang dibagikan semakin tinggi atau banyak maka investor akan menahan saham yang dimilikinya makatentunya volatilitas jual beli saham akan menurun dan membuat harga saham akan cenderung stabil. Hal ini didukung dengan penelitian yang dijalankan oleh (Shah and Noren, 2016) yang menyatakan bahwa dividendpolicy juga berpengaruh negatif terhadap share price volatility.

Earnings volatility menurut (Theresia dan Arilyn, 2015) . Earnings volatility menyebabkan laba sulit untuk diprediksi dan lebih sulit diprediksi lagi ketika volatilitasnya tinggi. Earning volatility diduga berpengaruh positif, dikarenakan jika laba yang naik turun tidak pasti, menyebabkan harga saham tidak stabil. Oleh karena itu tingkat volatilitas harga saham tidak baik atau pun cenderung tinggi. Hal ini didukung dengan penelitian yang dijalankan oleh (Shah and Noreen, 2016) yang menyatakan bahwa earning volatility berpengaruh positif terhadap share price volatility.

Kebijakan hutang ialah keputusan pendanaan oleh manajemen akan berpengaruh pada penelitian perusahaan yang terfleksi pada harga saham. Salah satu tugas manajer keuangan ialah menentukan kebijakan pendanaan yang dapat memaksimalkan harga saham yang merupakan cerminan dari suatu nilai perusahaan (Harmono, 2011). Kebijakan hutang diduga berpengaruh positif dikarenakan jika suatu manajemen perusahaan yang diketahui oleh para investor memiliki banyak hutang akan membuat investornya tidak akan mempertahankan saham yang dimiliki, karena kurangnya kepercayaan. Oleh karena itu volatilitas yang terjadi akan tinggi. Hal ini didukung dengan penelitian terdahulu oleh 
(Hooi et al., 2015) yang menyatakan bahwa kebijakan hutang berpengaruh positif terhadap share price volatility.

Growth asset menurut (Hestinoviana, 2013) adalah rata - rata pertumbuhan kekayaan perusahaan.Bila kekayaan awal suatu perusahaan adalah tetap jumlahnya, maka pada tingkat pertumbuhan aktiva yang tinggi berarti besarnya kekayaan akhir perusahaan tersebut semakin besar.Demikian pula sebaliknya, pada tingkat pertumbuhan aktiva yang tinggi bila besarnya kekayaan akhir tinggi berarti kekayaan awalnya rendah.Variabel ini juga dapat didefinisikan sebagai perubahan tahunan dari aktiva tetap. Hasil keputusan investasi yang tepat akan menghasilkan kinerja yang optimal maka dapat meningkatkan pertumbuhan asset perusahaan. Growthasset diduga berpengaruh negatif, dikarenakan jika pertumbuhan asset naik akan membuat para investor berani untuk menginvestasikan uangnya, tidak hanya untuk melakukan trading. Oleh karena itu tingkat volatilitas lebih rendah. Hal ini didukung dengan penelitian oleh (Kyle A and Frank W, 2013) yang menyatakan bahwa growthasset berpengaruh negatif terhadap share price volatility.

Menurut (Kasmir, 2012) Earning Per Share merupakan rasio untuk mengukur keberhasilan manajemen dalam mencapai keuntungan bagi para investor.Earnings per share atau laba per lembar saham adalah keuntungan bersih untuk tiap lembar sahamnya yang mampu diraih perusahaan pada saat menjalankan operasinya.Earnings per share adalah jumlah rupiah yang diperoleh oleh investor untuk setiap lembar saham atay laba bersih per lembar saham (Retnowati, 2013).EPS diduga berpengaruh negatif dikarenakan jika laba tetap dan pasti, maka harga saham tidak akan naik turun. Oleh karena itu volatilitas yang terjadi rendah.Hal ini didukung dengan penelitian oleh (Ngoc dan Cuong, 2016) yang menyatakan bahwa earning per share berpengaruh negatif terhadap share price volatility.

Dengan latar belakang tersebut diatas serta adanya perbedaan dalam bebeapa penelitian sebelumnya, maka menarik perhatian peneliti untuk meneliti kembali apakah kebijakan dividend, earning volatility, kebijakan hutang, growth asset dan EPS berpengaruh terhadap share price volatility.

\section{KAJIAN TEORI}

Dividend Signalling Theory. Dividend Signalling Theory (Teori Signalling) adalah menyatakan dividen alat yang digunakan mengirimkan isyarat kepada pasar mengenai hasil kerja perusahaan pada masa mendatang merupakan cara yang tepat, walaupun mahal tetapi berarti. Hanya perusahaan yang prospeknya baik yang dapat melakukan ini. Sedangkan perusahaan-perusahaan yang kurang, karena mereka tidak mempunyai arus kas yang cukup untuk melakukannya. Dengandemikian pasar akan bereaksi terhadap perubahan dividen yang dibayarkan, karena pasar yakin bahwa pemberi isyarat adalah perusahaan yang sukses (Khuniarji dan Raharja, 2013).

Kemudian dividend signaling theory dikembangkan oleh (Hooi et al., 2015) yaitu model yang dapat digunakan untuk menjelaskan mengapa perusahaan-perusahaan menggunakan dividen untuk memberikan isyarat walaupun menanggung kerugian saat melaksanakannya. Membagikan kas untuk pembayaran dividen merupakan hal yang mahal, karena perusahaan harus mampu menghasilkan kas yang cukup untuk mendukung pembayaran dividen secara tetap, dan karena kas dibayarkan untuk dividen maka akan mengurangi kesempatan berinvestasi dengan net present value (NPV) positif. Namun demikian bagi perusahaan yang prospeknya bagus dapat mengganti biaya ini (pembayaran dividen) melalui pengeluaran saham secara bertahap dengan harga yang semakin 
meningkat. Tetapi bagi perusahaan yang kurang sukses tidak dapat melakukan hal yang sama. Dengan demikian, memberikan isyarat melalui nilai dividen memberikan hasil yang positif.

Adanya teori ini membantu para investor mengetahui kondisi perusahaan yang ingin diinvestasikan. Ketika perusahaan memberikan signal bahwa dividen yang diberikan menurun, maka volatilitas harga akan naik, maka para investor akan mengetahui kondisi perusahaan yang sedang terjadi dari signal yang diberikan oleh perusahaan.

Agency Theory. Agency Theory (Teori Keagenan) adalah te suatu hubungan yang berdasarkan padakontrak yang terjadi antar para anggota dalam perusahaan, yakni antara principal (pemilik) dan agent (agen) sebagai pelaku utama (Anthony dan Govindarajan, 2011). Pemilik adalah suatu pihak yang memberikan mandat kepada agen untuk bertindak atas nama pemilik, sedangkan agen merupakan suatu pihak yang diberi mandat oleh pemilik untuk menjalankan perusahaan.

Hubungan keagenan didalam teori agensi (agency theory) bahwa perusahaan merupakan kumpulan kontrak (nexus of contract) antara pemilik sumber daya ekonomis (principal) dan manajer (agent) yang mengurus penggunaan dan pengendalian sumber daya tersebut (Jensen dan Meckling, 1976). Menurut (Shah dan Noreen, 2016) bahwa biaya agensi muncul ketika konflik kepentingan ada antara manajemen dan pemegang saham. Manajemen dapat menghabiskan banyak uang untuk membeli atau menambah investasi untuk memperbesar ukuran perusahaan mereka diluar ukuran optimal karena kompensasi eksekutif sering dikaitkan dengan ukuran perusahaan

Dengan teori ini menunjukkan terkadang perusahaan menyampaikan kondisi yang tidak sesuai dengan kondisi perusahaan yang sebenarnya. Kecurangan dilakukan oleh perusahaan untuk memperoleh keuntungan sebesar besarnya karena mementingkan kepentingan mereka sendiri, dan untuk meningkatkan kesejahteraan mereka, sehingga pada akhirnya menimbulkan konflik. Konflik antara manajemen seperti adanya salah satu pihak yang ingin membagikan dividen, tetapi juga ada pihak lain yang tidak setuju dalam membagikan dividen.

Efficient Market Hypothesis. Teori pasar efisien (Efficient Market) menurut (Wickramasinghe, 2016) bahwa dalam suatu pasar yang efisien harga akan mencerminkan sepenuhnya informasi yang tersedia dan sebagai implikasinya harga akan bereaksi secara seketika tanpa adanya bias terhadap informasi baru. Dalam pasar efisiensi, harga saham akan selalu berkolerasi atau mencerminkan semua informasi yang ada di pasar (Theresia dan Arilyn, 2015). Menurut (Nasution, 2015) efisiensi pasar (Efficient Market) sebagai hubungan antara harga - harga sekuritas saham dengan ketersediaan informasi

Konsep pasar efisien berkaitan dengan ketersediaan informasi. Pasar dapat dikatakan efisien apabila nilai sekuritas setiap waktu mencerminkan semua informasi yang tersedia, yang dapat mengakibatkan harga suatu sekuritas berada pada tingkat keseimbangannya. Harga keseimbangan suatu sekuritas mengakibatkan tidak adanya kesempatan yang diperoleh investor untuk mendapatkan return yang abnormal dari selisih harga sekuritas saham.

Efisiensi dapat diartikan sebagai seberapa cepat suatu pasar dapat menangkap informasi yang relevan yang pada nantinya akan tercermin pada harga saham. Dalam pasar yang memiliki informasi yang efisien, harga saham akan dipengaruhi oleh semua informasi yang tersedia baik itu mengenai manajemen, keuntungan, produk suatu 
perusahaan, dan informasi yang menurut investor penting. Harga pasar akan secara cepat berubah sebagai dampak dari adanya informasi tersebut.

Share Price Volatility. Menurut (Sadiq et al., 2013) Volatilitas harga saham adalah naik dan turunnya harga saham dalam suatu periode waktu. (Habib et al., 2012) menyatakan volatilitas harga saham di sisi lain adalah risiko sistemik yang hanya dihadapi oleh para investor yang berinvestasi pada saham biasa. Volatilitas terjadi karena masuknya informasi baru ke dalam pasar atau bursa. Akibatnya para pelaku pasar melakukan penilaian kembali dengan aset yang diperjualbelikan. Volatilitas harga saham menurut (Hussainey et al., 2011) adalah ukuran dalam menentukan resiko dalam investasi dan dapat menunjukan tingkat perubahan stock price selama jangka waktu tertentu.

Berdasarkan pengertian diatas, maka disimpulkan bahwa volatilitas harga saham merupakan risiko yang harus ditanggung oleh para investor dalam investasinya. volatilitas harga saham yang tinggi akan menyebabkan penilaian kembali oleh para investornya karena dianggap adalah naik dan turunnya harga saham dalam suatu periode waktu karena masuknya informasi baru ke dalam pasar atau bursa yang mengakibatkan para pelaku pasar melakukan penilaian kembali dengan aset yang diperjualbelikan.

Kebijakan Dividen. Dividend yield adalah tingkat pengembalian berupa dividen atas investasi yang telah ditanamkan oleh investor. Hal tersebut dapat berpengaruh terhadap keputusan investasi seorang investor, serta perubahan keputusan investasi dapat berdampak pada volatilitas atau harga saham. Menurut penelitian (Kyle A, Frank W, 2013), (Hooi et al., 2015), dan (Shah dan Noreen, 2016), dijelaskan bahwa perusahaan yang memiliki dividend yield cenderung meningkat, akan membuat investor lebih memilih mencari posisi aman dengan menahan saham yang ditanamkan di perusahaan. dengan keadaan tersebut, maka akan membuat harga saham cenderung stabil sehingga volatilitas harga saham menjadi rendah.

Pendapat berbeda ditekankan oleh penelitian yang dijalankan oleh (Stephen et al., 2015), (Shah dan Noreen, 2016), (Jahfeer dan Hameed, 2016), (Ilaboya dan Aggreh, 2013), dan (Ngoc dan Cuong, 2016), yang menjelaskan bahwa dividend yield yang semakin tinggi membuat pergerakan harga saham semakin ekstrim. Hal ini terjadi karena dividend yield yang semakin tinggi akan langsung melambungkan harga saham perusahaan karena banyaknya minat untuk membeli saham perusahaan. Dengan melambungnya harga saham ini akan membuat volatilitas harga saham akan menjadi tinggi.

Earnings Volatility. (Theresia dan Arilyn, 2015) menyatakan earning volatility adalah laba fluktuatif dari suatu perusahaan yang mencerminkan risiko dari aktivitas operasi perusahaan. Hal ii akan mempengaruhi keputusan investor mengenai risiko yang terjadi pada suatu perusahaan.

Menurut hasil penelitian yang dijalankan oleh (Shah, Noreen, 2016) dan (Jahfeer dan Hameed, 2016), dijelaskan pengaruh antara Earnings Volatility terhadap Share Price Volatility, dimana didapatkan hasil bahwa Earnings Volatility berpengaruh positif terhadap Share Price Volatility. Hal ini terjadi karena semakin tinggi volatilitas pendapatan sebuah perusahaan maka akan menggerakan harga saham karena kinerja perusahaan dinilai dari earnings dan dengan earnings yang bergejolak atau fluktuatif, maka pada saat yang bersamaan, harga saham juga akan bergejolak. Dengan keadaan 
tersebut maka akan membuat nilai Earnings Volatility yang tinggi juga akan meningkatkan Share Price Volatility.

Penelitian lain yang dijalankan oleh (Habib et al., 2012) dan (Hooi et al., 2015), menjelaskan bahwa Earnings Volatility tidak akan berpengaruh terhadap Share Price Volatility karena pada dasarnya banyak perusahaan dengan tingkat earnings yang rendah masih bisa dan mampu membagikan dividen dan banyak perusahaan dengan earnings tinggi cenderung menahan keuntungan mereka sebagai modal di periode mendatang sedangkan pemegang saham cenderung memilih perusahaan dari dividen bukanlah dari earnings. (Ilaboya dan Aggreh, 2013) menjelaskan pendapat berbeda dimana hasil dari penelitian menjelaskan bahwa Earnings Volatility berpengaruh negatif terhadap Share Price Volatility karena adanya kemungkinan industri yang diteliti cenderung memang memiliki ciri earnings yang fluktuatif sehingga dengan earnings yang fluktuatif membuat para pemegang saham melihat kondisi tersebut sebagai kondisi yang baik dan cenderung menahan saham mereka.

Debt Policy. Menurut (Riyanto, 2011) kebijakan hutang adalah keputusan kebijakan yang diambil oleh pihak manajemen dalam rangka memperoleh sumber pembiayaan bagi perusahaan sehingga dapat digunakan untuk membiayai aktivitas operasional perusahaan. Dimana kebijakan hutang merupakan keputusan yang penting bagi perusahaan.

(Ilaboya dan Anggreh, 2013) menjelaskan hasil penelitian mengenai pengaruh Debt Policy dengan Share Price Volatility dimana hasil penelitian menjelaskan terdapat pengaruh positif Signifikan dari Debt Policy terhadap Share Price Volatility. Hal ini terjadi karena perusahaan dengan hutang tinggi cenderung sulit untuk diprediksi sehingga dengan meningkatnya tingkat hutang perusahaan, akan memunculkan kekhawatiran dari pemegang saham sehingga akan terjadi fluktuasi saham sebuah perusahaan. Dengan keadaan tersebut, membuat semakin tinggi tingkat hutang perusahaan akan semakin fluktuatif harga saham perusahaan tersebut.

Temuan lain dihasilkan dari penelitian yang dijalankan oleh (Jahfeer dan Hameed, 2016) dan (Habib et al., 2012), yang menjelaskan pengaruh tidak signifikan dari Debt Policy terhadap Share Price Volatility hal ini terjadi karena pada dasarnya Debt Policy tidak selalu menjadi momok yang menunjukkan ketidakmampuan finansial perusahaan untuk mendanai aset mereka.

Growth Asset. Pertumbuhan aset menggunakan pertumbuhan masa lalu dan profitabilitas untuk prediksi pertumbuhan laba di masa depan (Reilly dan Brown, 2012). (Kyle A and Frank W, 2013), menjelaskan pengaruh negatif antara growth dengan share price volatility. Hal ini dapat terjadi karena growth yang semakin tinggi menunjukkan adanya kestabilan dari sisi kinerja perusahaan dan membuat pemegang saham cenderung akan menunggu perkembangan perusahaan sehingga akan menahan saham yang dimiliki. Dengan keadaan ini maka semakin tinggi growth perusahaan, maka akan semakin menurunkan volatilitas harga saham perusahaan itu.

Hasil penelitian lain dikemukakan oleh (Ngoc dan Cuong, 2016), (Shah dan Noreen, 2016), (Habib et al., 2012), (Hooi et al., 2015), dan (Sadiq et al., 2013), yang menunjukkan hasil positif dari growth terhadap share price volatility. Hal ini terjadi karena growth yang semakin tinggi menunjukkan pertumbuhan aset yang semakin tinggi juga. Dengan aset yang semakin besar, namun tidak didukung dengan kesejahteraan para pemegang saham, maka akan membuat terjadinya fluktuasi harga saham yang tinggi dalam sebuah periode. 
Earning Per Share. (Ngoc dan Cuong, 2016), dalam penelitiannya menjelaskan pengaruh Earning Per Share terhadap Share Price Volatility yang bersifat negatif. Hal ini terjadi karena perusahaan dengan tingkat earnings per share yang tinggi akan memberikan dorongan investor untuk bertahan karena earnings per share menunjukkan keuntungan yang didapatkan investor saat menahan saham di perusahaan. Dengan tawaran tingkat earnings per share yang terus meningkat akan mendorong stabilnya harga saham perusahaan karena peningkatannya tidak akan fluktuatif. Dengan keadaan tersebut maka semakin tinggi earnings per shareakan menurunkan fluktuasi pada harga saham.

Pendapat lain dikemukakan oleh penelitian (Shah dan Noreen, 2016), (Wickramasinghe, 2016), yang menyatakan bahwa pengaruh Earning Per Share terhadap Share Price Volatility bersifat positif. Hal ini dapat saja terjadi saat terdapat permasalahan dalam fundamental negara. Selain itu, berita yang muncul serta frekuensi dalam menyebarkan informasi mengenai Earning Per Share dapat membuat saham perusahaan menjadi fluktutatif. (Sadiqet al., 2013), menunjukkan hasil penelitian bahwa Earning Per Share tidak berpengaruh terhadap Share Price Volatility.

\section{Hipotesis}

Adapun hipotesis yang diajukan dalam penelitian ini adalah :

$\mathrm{H}_{1}$ : Kebijakan Dividen memiliki pengaruh negatif terhadap Share Price Volattility

$\mathrm{H}_{2}$ : Earning Volatility memiliki pengaruh positif terhadap Share Price Volatility.

$\mathrm{H}_{3}$ : Kebijakan Hutang memiliki pengaruh positif terhadap Share Price Volatility.

$\mathrm{H}_{4}$ : GrowthAssetmemiliki pengaruh negatif terhadap Share Price Volatility.

$\mathrm{H}_{5}$ : Earning Per Sharememiliki pengaruh negatif terhadap Share Price Volatility

Model penelitian yang akan diuji adalah sebagai berikut :

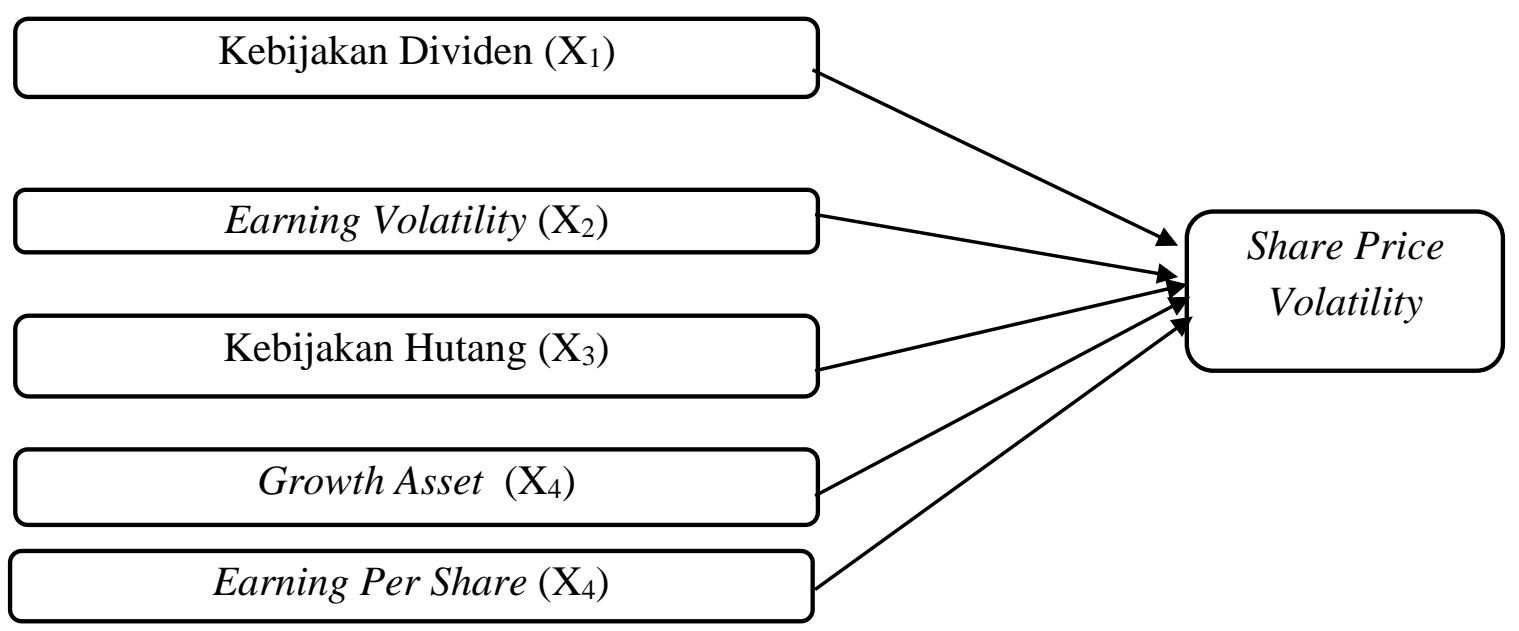

Gambar 1. Model Penelitian

\section{METODE}

Dalam penelitian ini yang menjadi populasi adalah seluruh data perusahaan manufaktur periode 2015-2017. Sampel dalam penelitian ini adalah 35 perusahaan manufaktur.Obyek penelitian dalam penelitian ini adalah kebijakan dividen, earning volatility, kebijakan hutang, asset growth dan earning per share. Penelitian ini 
menggunakan metode purposive sampling yaitu metode pengambilan sampel sumber data dengan pertimbangan tertentu (Sugiyono, 2014).

Kriteria dalam pemilihan sampel yang digunakan dalam penelitian ini adalah (1)Perusahaan manufaktur yang terdaftar di Bursa Efek Indonesia (BEI) secara berturutturut tahun 2015-2017, (2)Perusahaan manufaktur yang terdaftar di Bursa Efek Indonesia (BEI) dan menyajikan laporan keuangan dalam mata uang rupiah, (3) Perusahaan manufaktur yang terdaftar di Bursa Efek Indonesia (BEI) dan selalu membagikan dividen selama periode 2015-2017.

Penelitian ini menggunakan analisis regresi berganda karena dalam penelitian ini menggunakan satu variabel dependen dan lima variabel independen. Pengolahan data dalam penelitian ini menggunakan program Eviews 9.0 for Windows.

$$
Y_{i t}=\alpha+\beta_{1} D Y_{i, t}+\beta_{\mathbf{2}} E V_{i t}+\beta_{3} D E B T_{i t}+\beta_{\mathbf{4}} G A_{i t}+\beta_{5} E P S_{i t}+\varepsilon_{i t}
$$

Keterangan:

$\begin{array}{ll}\text { Y } & : \text { Share Price Volatility } \\ \alpha & : \text { Konstanta } \\ \beta_{\mathbf{1}}, \beta_{\mathbf{2}}, \beta_{\mathbf{3}}, \beta_{\mathbf{4}}, \beta_{\mathbf{5}}: \text { Koefisien Regresi } \\ \text { DY } & : \text { Kebijakan Dividen } \\ \text { EV } & : \text { Earnings Volatility } \\ \text { DEBT } & : \text { Kebijakan Hutang } \\ \text { GA } & : \text { Growth Asset } \\ \text { EPS } & : \text { Earning Per Share } \\ \varepsilon & : \text { Error }\end{array}$

Operasionalisasi variabel yang digunakan dalam penelitian ini adalah:

Variabel dependen adalah Share Price Volatility. Menurut (Hooi et al., 2015) rumus untuk menghitung share price volatility adalah sebagai berikut:

$S P V=\sqrt{\frac{\sum_{i=1}^{n}\left(\frac{H_{i}-L_{i}}{\left.\frac{H_{i}+L_{i}}{2}\right)^{2}}\right.}{n}}$

Keterangan :

$\mathrm{Hi}=$ harga saham tertinggi pada tahun yang bersangkutan

$\mathrm{Li}=$ harga saham terendah pada tahun yang bersangkutan

Variabel independen yang digunakan adalah:

Kebijakan Deviden adalah kebijakan untuk menentukan berapa laba yang harus dibayarkan (dividen) kepada pemegang saham dan berapa banyak yang harus ditanam kembali (laba ditahan). Menurut (Stephen et al., 2015), rumus untuk menghitung kebijakan dividen adalah sebagai berikut :

$D Y=\sum_{i=1}^{n}\left(\frac{D_{i}-M V_{i}}{n}\right)$ 
Earnings Volatility adalah tingkat volatilitas (perubahan yang cepat) dari keuntungan yang didapatkan perusahaan. Menurut (Hooi et al., 2015) rumus untuk menghitung kebijakan dividen adalah sebagai berikut :

$E V=\sqrt{\frac{\sum_{i=1}^{n}\left(R_{i}-R_{a}\right)^{2}}{n}}$

Kebijakan hutang merupakan kebijakan pendanaan perusahaan yang bersumber dari eksternal. Menurut (Hooi et al., 2015) rumus untuk menghitung kebijakan dividen adalah sebagai berikut :

$$
\text { Debt }=\frac{\sum_{i=1}^{n} \frac{\text { Long Term } \text { Debt }_{i}}{\text { Total } \text { Asset }_{i}}}{n}
$$

Growth assets merupakan persentase peningkatan dalam nilai aset. Menurut (Hooi et al., 2015) rumus untuk menghitung kebijakan dividen adalah sebagai berikut :

Asset Growth $=\frac{\sum_{i=\mathbf{1}}^{n} \frac{\Delta \text { Asset }_{i}}{\text { Asset }_{i}}}{n}$

Keterangan: $\mathrm{n}=$ total periode/tahun

EPS adalah laba yang didapatkan oleh investor yang didapatkan dalam setiap lembar saham. Menurut (Wickramasinghe, 2016) rumus untuk menghitung kebijakan dividen adalah sebagai berikut $=$ :

$E P S=\frac{\text { Total Earning for the year }}{\text { Number of equity share outstanding }}$

\section{HASIL DAN PEMBAHASAN}

Statistik Deskriptif. Deskripsi mengenai subyek didalam penelitian ini disajikan dalam bentuk statistik deskriptif. Analisis statistik deskriptif adalah alat analisis yang digunakan untuk menganalisis data dengan menggambarkan atau mendeskripsikan data-data yang telah terkumpul tanpa bermaksud untuk membuat kesimpulan yang berlaku umum (Sugiyono, 2014). Statistik deskriptif dapat memberikan gambaran mengenai mean (ratarata hitung), median (nilai tengah), nilai minimum, nilai maksimum, dan deviation standard (simpangan baku).

Tabel 1. Hasil Analisis Statistik Deskriptif

\begin{tabular}{lllllll}
\hline & SV & DY & EV & DEBT & GA & EPS \\
\hline Mean & 924.8286 & 1.478236 & 0.034400 & 0.032034 & 0.031476 & 1039.685 \\
Median & 212.1320 & 0.810000 & 0.024500 & 0.019900 & 0.025300 & 126.0000 \\
Maximum & 9563.619 & 6.666700 & 0.183800 & 0.157100 & 0.169200 & 5219.310 \\
\hline
\end{tabular}




\begin{tabular}{lllllll}
\hline Minimum & 8.013900 & 0.007700 & 0.000013 & 0.001600 & -0.057900 & -104.6600 \\
Std. Dev. & 1715.974 & 1.740758 & 0.031925 & 0.028434 & 0.038936 & 1484.448 \\
& & & & & & \\
& & 105 & 105 & 105 & 105 & 105 \\
\hline \multicolumn{2}{l}{ Observations 105 } & 105
\end{tabular}

Sumber: Hasil Output Statistik deskriptif dengan program Eviews 9.0

\section{Hasil Uji Asumsi Analisis Data}

1. Uji Common Effect

Berikut hasil uji dari common effect:

Tabel 2. Common Effect

\begin{tabular}{lllll}
\hline \hline Variable & Coefficient & Std. Error & t-Statistic & Prob. \\
\hline \hline C & 887.6968 & 460.7685 & 1.926557 & 0.0569 \\
DY & -122.0996 & 93.60931 & -1.304353 & 0.1951 \\
EV & 14737.58 & 5359.550 & 2.749779 & 0.0071 \\
DEBT & -1707.357 & 6122.649 & -0.278859 & 0.7809 \\
GA & 1171.804 & 4024.291 & 0.291183 & 0.7715 \\
EPS & -0.261174 & 0.115801 & -2.255372 & 0.0263 \\
\hline \hline & & & \\
R-squared & 0.189580 & Mean dependent var & 924.8286 \\
Adjusted R-squared & 0.148649 & S.D. dependent var & 1715.974 \\
S.E. of regression & 1583.306 & Akaike info criterion & 17.62786 \\
Sum squared resid & $2.48 E+08$ & Schwarz criterion & 17.77952 \\
Log likelihood & -919.4628 & Hannan-Quinn criter. & 17.68932 \\
F-statistic & 4.631769 & Durbin-Watson stat & 1.333079 \\
Prob(F-statistic) & 0.000770 & & & \\
\hline \hline
\end{tabular}

Sumber: Hasil pengolahan data menggunakan Eviews 9.0

Dari Tabel 2, dapat dilihat besarnya nilai adjusted $r$ squared sebesar 0.148649 artinya variabel dependen dapat dijelaskan oleh variabel independen dalam model common effect ini sebesar $14,86 \%$ sedangkan sisanya $85,14 \%$ dijelaskan oleh variabelvariabel lain.Selanjutnya hasil ini akan dibandingkan dengan hasil pengujian menggunakan model fixed effect untuk melihat model manakah yang paling tepat digunakan dalam penelitian ini.

\section{Uji Fixed Effect}

Berikut hasil uji dariFixed Effect: 
Tabel 3. Fixed Effect

\begin{tabular}{lllll}
\hline \hline Variable & Coefficient & Std. Error & t-Statistic & Prob. \\
\hline \hline C & 1315.187 & 621.2268 & 2.117081 & 0.0381 \\
DY & 14.83410 & 122.5078 & 0.121087 & 0.9040 \\
EV & -3501.332 & 11748.89 & -0.298014 & 0.7666 \\
DEBT & -5610.427 & 9660.347 & -0.580769 & 0.5634 \\
ASSET & 3631.397 & 3960.681 & 0.916862 & 0.3626 \\
EPS & -0.217775 & 0.159033 & -1.369371 & 0.1756 \\
\hline \hline
\end{tabular}

Effects Specification

Cross-section fixed (dummy variables)

\begin{tabular}{llll}
\hline \hline R-squared & 0.641059 & Mean dependent var & 924.8286 \\
Adjusted R-squared & 0.425694 & S.D. dependent var & 1715.974 \\
S.E. of regression & 1300.416 & Akaike info criterion & 17.46109 \\
Sum squared resid & $1.10 \mathrm{E}+08$ & Schwarz criterion & 18.47212 \\
Log likelihood & -876.7071 & Hannan-Quinn criter. & 17.87078 \\
F-statistic & 2.976616 & Durbin-Watson stat & 2.718261 \\
Prob(F-statistic) & 0.000049 & & \\
\hline \hline
\end{tabular}

Sumber: Hasil pengolahan data menggunakan Eviews 9.0

Dari Tabel 3, dapat dilihat dengan modelfixed effect besarnya nilai adjusted $r$ squared adalah sebesar 0,425694 artinya variabel independen dapat menjelaskan variabel dependen sebesar $42,57 \%$ sedangkan sisanya 57,43\% dijelaskan oleh variabel lain diluar penelitian ini.Tahap selanjutnya adalah dilakukan Redundant Fixed Effects-Likehood Ratio (Uji Chow) untuk menentukan model mana yang lebih tepat digunakan antara common effect dan fixed effect model.

\section{Uji Chow}

Chow Testdigunakan untuk menentukan common effect modelataufixed effect model dengan uji hipotesis:

$\mathrm{H}_{0}:$ Common Effect Model

$\mathrm{H}_{1}$ : Fixed Effect Model

Hasil uji Redundant Fixed Effect Test (Chow Test) dapat dilihat dengan nilai probability. Apabila probability cross section $\mathrm{F}$ lebih besar dari angka 0,05 pada tingkat signifikansi $5 \%$, maka hipotesis nol tidak ditolak. Namun, jika nilai probability cross section $\mathrm{F}$ lebih kecil dari nilai 0,05 maka hipotesis nol ditolak. Sehingga, apabila $\mathrm{H}_{0}$ ditolak maka Fixed Effect Model yang dipilih untuk proses selanjutnya.

Berikut hasil uji dari Chow: 
Tabel 4. Chow

Redundant Fixed Effects Tests

Equation: Untitled

Test cross-section fixed effects

\begin{tabular}{llll}
\hline \hline Effects Test & Statistic & d.f. & Prob. \\
\hline \hline Cross-section F & 2.404630 & $(34,65)$ & 0.0012 \\
Cross-section Chi-square & 85.511339 & 34 & 0.0000 \\
\hline \hline
\end{tabular}

Sumber: Hasil pengolahan data menggunakan Eviews 9.0

Dari Tabel 4 dapat dilihat hasil uji Chow bahwa nilai Cross-section F sebesar 0.0012 dan cross section chi-square sebesar 0.0000 atau lebih kecil dari 0.05 . Apabila nilai crosssection $F$ dan cross section chi-square lebih kecil dari 0.05 maka $\mathrm{H}_{0}$ ditolak dan $\mathrm{H}_{1}$ diterima.

Dari tabel tersebut dapat dilihat bahwa hasil yang diperoleh lebih kecil dari 0,05 sehingga dapat dikatakan bahwa model yang lebih tepat digunakan adalah Fixed effect. Tahap selanjutnya akan dilakukan Haussman test untuk membandingkan pendekatan model fixed effect dan model random effect. Apabila data cross section lebih banyak jika dibandingkan dengan data time series maka dapat dilakukan denganpendekatan model random effect.

\section{Uji Random Effect}

Berikut hasil uji dari Random Effect:

Tabel 5. Random Effect

\begin{tabular}{lllll} 
Variable & Coefficient & Std. Error & t-Statistic & Prob. \\
\hline \hline C & 879.0039 & 487.0637 & 1.804700 & 0.0742 \\
DY & -70.21518 & 96.18461 & -0.730004 & 0.4671 \\
EV & 12184.71 & 6178.326 & 1.972170 & 0.0514 \\
DEBT & -2782.299 & 6628.206 & -0.419766 & 0.6756 \\
GA & 2921.109 & 3633.807 & 0.803870 & 0.4234 \\
EPS & -0.261955 & 0.120118 & -2.180814 & 0.0316 \\
\hline \hline
\end{tabular}

Effects Specification

S.D. Rho

\begin{tabular}{lll}
\hline \hline Cross-section random & 925.1555 & 0.3360 \\
Idiosyncratic random & 1300.416 & 0.6640 \\
\hline \hline
\end{tabular}

Weighted Statistics

\begin{tabular}{llll}
\hline \hline R-squared & 0.116903 & Mean dependent var & 582.7724 \\
Adjusted R-squared & 0.072302 & S.D. dependent var & 1354.896
\end{tabular}




\begin{tabular}{llll} 
S.E. of regression & 1304.996 & Sum squared resid & $1.69 \mathrm{E}+08$ \\
F-statistic & 2.621087 & Durbin-Watson stat & 1.791641 \\
Prob(F-statistic) & 0.028644 & & \\
\hline \hline & Unweighted Statistics & \\
\hline \hline & & & \\
R-squared & 0.181980 & Mean dependent var & 924.8286 \\
Sum squared resid & $2.51 \mathrm{E}+08$ & Durbin-Watson stat & 1.290551 \\
\hline \hline
\end{tabular}

Sumber: Hasil pengolahan data menggunakan Eviews 9.0

Dari Tabel 5 diatas, dapat dilihat bahwa dengan pendekatan model random effect terdapat satu variabel independen yang mempengaruhi variabel dependen, yaitu EarningPer Share.Dalam pendekatan model random effect ini nilai r-squared sebesar 0.116903 atau sebesar 11,69\%, dimana nilai ini lebih kecil dibandingkan dengan pendekatan model fixed effect yang mempunyai nilai $r$-squared sebesar $64,11 \%$.Setelah diperoleh hasil dari pendekatan model random effect, tahap selanjutnya akan dilakukan pengujian Hausman Specification Testuntuk menentukan pendekatan mana yang lebih cocok digunakan dalam penelitian ini apakah pendekatan model fixed effectatau model random effect.

\section{Uji Hausmann}

Berikut hasil uji dariHausmann:

Tabel 6. Hausmann

Correlated Random Effects - Hausman Test

Equation: Untitled

Test cross-section random effects

\begin{tabular}{llll}
\hline \hline Test Summary & $\begin{array}{l}\text { Chi-Sq. } \\
\text { Statistic }\end{array}$ & Chi-Sq. d.f. & Prob. \\
\hline \hline Cross-section random & 5.698547 & 5 & 0.3367 \\
\hline \hline
\end{tabular}

Sumber: Hasil pengolahan data menggunakan Eviews 9.0

Dari Tabel 6 dapat dilihat bahwa nilai dari probabilitas pada cross-section random adalah 0.3367. Pada tingkat signifikansi 5\% jika probabilitas pada cross-section random lebih kecil dari 0.05 maka $\mathrm{H}_{0}$ ditolak dan $\mathrm{H}_{1}$ diterima dengan hipotesis sebagai berikut:

$\mathrm{H}_{0}$ : Model Random effect

$\mathrm{H}_{1}$ : Model Fixed effect

Berdasarkan hasil pengujian menggunakan correlated random effect, maka dapat disimpulkan bahwa pendekatan yang lebih tepat untuk digunakan dalam penelitian ini adalah model random effect. Hal ini berarti terdapat ketidak konsistenan hasil antara uji Chow dengan uji Hausman.Dalam uji Chow ditemukan bahwa pendekatan yang lebih tepat digunakan adalah model fixed effect, sedangkan di dalam uji Hausman ditemukan 
pendekatan yang lebih tepat digunakan adalah model random effect. Oleh karena itu dibutuhkan pengujian lagi untuk menentukan pendekatan model mana yang akan digunakan yaitu dengan menggunakan uji Lagrange Multiplier.

\section{Uji Lagrange Multiplier}

Berikut hasil uji dariLagrange Multiplier:

Tabel 7. Lagrange Multiplier

\begin{tabular}{llll}
\hline \hline $\begin{array}{l}\text { Null (no rand. effect) } \\
\text { Alternative }\end{array}$ & $\begin{array}{l}\text { Cross-section } \\
\text { One-sided }\end{array}$ & $\begin{array}{l}\text { Period } \\
\text { One-sided }\end{array}$ & Both \\
\hline \hline \multirow{2}{*}{ Breusch-Pagan } & 8.435232 & 0.239953 & $\begin{array}{l}8.675185 \\
\text { Honda }\end{array}$ \\
& $(0.0037)$ & $(0.6242)$ & $(0.0032)$ \\
King-Wu & 2.904347 & -0.489850 & 1.707307 \\
& $(0.0018)$ & $(0.6879)$ & $(0.0439)$ \\
GHM & 2.904347 & -0.489850 & 0.208512 \\
& $(0.0018)$ & $(0.6879)$ & $(0.4174)$ \\
& -- & -- & 8.435232 \\
& -- & -- & $(0.0055)$ \\
\hline \hline
\end{tabular}

Sumber: Hasil pengolahan data menggunakan Eviews 9.0

Berdasarkan hasil uji Lagrange Multiplier (LM) dalam Tabel 7, dapat dilihat bahwa nilai probabilitas Breusch-Pagan pada kolom Both adalah sebesar 0,0032. Pada tingkat signifikansi 5\%, jika nilai probabilitas Breusch-Pagan pada kolom Both lebih kecil dari 0.05 maka $\mathrm{H}_{0}$ ditolak dan $\mathrm{H}_{1}$ diterima.dengan hipotesis sebagai berikut :

$\mathrm{H}_{0}$ : Model Common effect

$\mathrm{H}_{1}$ : Model Random effect

Dari hasil pengujian diatas dapat disimpulkan bahwa pendekatan yang paling tepat digunakan dalam penelitian ini adalah model random effect.Setelah dilakukan pengujian denganHausman test dan LM test ditemukan hasil yang sama bahwa pendekatan yang paling sesuai digunakan dalam penelitian ini adalah model random effect.

\section{Uji Regresi}

Setelah dilakukan pengujian diatas maka didapatkan hasil bahwa model random effect merupakan pendekatan yang paling sesuai digunakan dalam peneltiian ini.Berdasarkan tabel 4.5 Random Effect diperoleh model penelitian sebagai berikut:

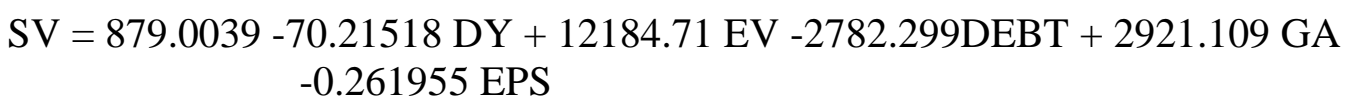

Berdasarkan persamaan regresi linear berganda yang sudah dirumuskan diatas, dapat disimpulkan bahwa nilai konstanta sebesar 879.0039 yang artinya jika kebijakan dividen, earning volatility, kebijakan hutang, growth asset dan EPS bernilai nol maka nilai share price volatility adalah 879.0039. Koefisien regresi kebijakan dividen menunjukkan nilai sebesar -70.21518yang berarti jika kebijakan dividen mengalami kenaikan sebesar 1 
satuan, maka nilai share price volatility akan mengalami penurunan sebesar 70.21518 dengan asumsi variabel independen lainnya bernilai konstan atau tetap. Koefisien regresi Earning Volatility menunjukkan nilai sebesar 12184.71yang berarti jika Earning Volatility mengalami kenaikan sebesar 1 satuan, maka nilai share price volatility akan mengalamai kenaikansebesar 12184.71 dengan asumsi variabel independen lainnya bernilai konstan atau tetap. Koefisien regresi kebijakan hutang menunjukkan nilai sebesar -2782.299 yang berarti jika kebijakan hutang mengalami kenaikan sebesar 1 satuan, maka nilai share price volatility akan mengalami penurunansebesar 2782.299 dengan asumsi variabel independen lainnya bernilai konstan atau tetap. Koefisien regresi Growth Asset menunjukkan nilai sebesar 2921.109 yang berarti jika Growth Asset mengalami kenaikan sebesar 1 satuan, maka nilai share price volatility akan mengalami kenaikansebesar 2921.109 dengan asumsi variabel independen lainnya bernilai konstan atau tetap. Koefisien regresiEPS menunjukkan nilai sebesar -0.261955yang berarti jika EPSmengalami kenaikan sebesar 1 satuan, maka nilai share price volatility akan mengalami penurunansebesar 0.261955 dengan asumsi variabel independen lainnya bernilai konstan atau tetap.

Dari Tabel 5 di atas, terlihat nilai Adjusted $R$ Square sebesar 0.072302 yang berarti kontribusi dari variabel kebijakan dividen, earning volatility, kebijakan hutang, growth asset dan EPS dalam memprediksi variabel share price volatility adalah sebesar $7.23 \%$ sedangkan masih terdapat $92.77 \%$ faktor lain yang turut mempengaruhi share price volatility di luar kebijakan dividen, earning volatility, kebijakan hutang, growth asset dan EPS. Dari hasil uji F ditemukan nilai prob (F-statistic) sebesar 0.028644.Dengan tingkat nilai signifikansi lebih kecil dari 0.05 maka dapat disimpulkan bahwa.modelregresi yang digunakan layak.

Pembahasan. Hipotesis yang pertama diajukan dalam penelitian ini adalah Dividend Yield berpengaruh negatif terhadapshare price volatility. Berdasarkan kesimpulan hasil pengujian hipotesis pada Tabel 5, menunjukkan bahwa nilai standardized coefficient sebesar -70.21518 yang berarti menghasilkan arah yang negatif dan nilai probabilitas sebesar 0.4671 yang lebih besar dari tingkat signifikansi $\alpha=0.05$ sehingga dapat disimpulkan bahwa kebijakan dividen tidak berpengaruh terhadap share price volatility dan artinya hipotesis pertama ditolak.Hasil uji hipotesis ini sesuai dengan penelitian (Wickramasinghe, 2016), (Jahfer dan Hameed, 2016) dan tidak sesuai dengan hasil penelitian yang dilakukan oleh (Kyle A and Frank W, 2013), (Hooi et al., 2015), dan (Shah dan Noreen, 2016) yang menyatakan bahwa kebijakan dividen berpengaruh negatif terhadap share price volatility.Kebijakan dividen menggambarkan tingkat pertumbuhan perusahaan kita dapat mengenali tahap kehidupan perusahaan dengan cara melihat dari pembagian dividennya. Dalam menyampaikan informasi mengenai keadaan perusahan, maka perusahaan menggunakan teori signaling. Signal yang didapatkan oleh investor dapat digunakan untuk mengirimkan isyarat kepada pasar mengenai hasil kerja perusahaan pada masa mendatang. Hasil dari pengujian hipotesis pertama ini tidak sesuai dengan hipotesis yang diajukan diawal penelitian ini yang menunjukkan hasil bahwa kebijakan dividen tidak berpengaruh terhadap tingkat share price volatility. Penyebab tidak berpengaruhnya kebijakan dividen terhadap share price volatility disebabkan karena walaupun kebijakan dividen yang ditawarkan atau dibagikan oleh perusahaan tinggi, namun apabila tidak diimbangi dengan kemampuan perusahaan dalam menerbitkan informasi yang transparan kepada pemegang saham dapat membuat rasa khawatir dari pemegang saham. Selain itu, pengaruh yang tidak signifikan juga bisa muncul karena investor tidak melihat hanya dari informasi kebijakan dividen saja dalam melakukan 
perdagangan saham, namun rasio keuangan yang mencerminkan kinerja perusahaan menjadi penentu investor dalam membeli saham sebuah perusahaan. Walaupun kebijakan dividen relatif tinggi, tetapi jika tidak diimbangi dengan rasio keuangan yang stabil maka tidak akan mempengaruhi share price volatility.

Hipotesis kedua yang diajukan dalam penelitian ini adalah earning volatility berpengaruh positif terhadapshare price volatility. Berdasarkan kesimpulan pengujian hipotesis pada Tabel 5, menunjukkan bahwa nilai standardized coefficient sebesar 12184.71 yang berarti menghasilkan arah yang positif dan nilai probabilitas sebesar 0.0514 yang lebih besar dari tingkat signifikansi $\alpha=0.05$ sehingga dapat disimpulkan bahwa earning volatility tidak berpengaruh terhadap share price volatility dan artinya hipotesis kedua ditolak.Hasil uji hipotesis ini sesuai dengan penelitian (Theresia dan Arilyn, 2015) dan tidak sesuai dengan hasil penelitian yang dilakukan oleh (Shah and Noreen, 2016) dan (Jahfeer dan Hameed, 2016) yang menyatakan bahwa earning volatility berpengaruh positif terhadap share price volatility.Earning volatility merupakan tingkat naik turunnya laba atau tingkat fluktuatif laba yang mencerminkan risiko dari aktivitas operasi perusahaan.Hasil dari pengujian hipotesis kedua ini tidak sesuai dengan hipotesis yang diajukan diawal penelitian ini.

Penyebab tidak berpengaruhnya earning volatility terhadap share price volatility disebabkan dikarenakan share price volatility akan meningkat atau menurun besar dipengaruhi oleh pembagian dividen dari perusahaan itu sendiri, sedangkan pembagian dividen tetap bisa dibagikan walaupun kinerja perusahaan mengalami volatilitas yang tinggi dikarenakan masih adanya retained earnings, sehingga walaupun earnings perusahaan mengalami fluktuasi yang yang besar, selama perusahaan tersebut bisa memerhatikan kesejahteraan pemegang saham dengan pembagian dividen, maka investor akan tetap percaya dengan perusahaan dan tidak akan mempengaruhi volatilitas dari harga saham perusahaan

Hipotesis ketiga yang diajukan dalam penelitian ini adalah kebijakan hutang berpengaruh positif terhadapshare price volatility. Berdasarkan kesimpulan pengujian hipotesis pada Tabel 5, menunjukkan bahwa nilai standardized coefficient sebesar 2782.299 yang berarti menghasilkan arah yang negatif dan nilai probabilitas sebesar 0.6756 yang lebih besar dari tingkat signifikansi $\alpha=0.05$ sehingga dapat disimpulkan bahwa kebijakan hutang tidak berpengaruh terhadap share price volatility dan artinya hipotesis ketiga ditolak. Hasil uji hipotesis ini sesuai dengan penelitian (Jahfer dan Hameed, 2016) dan tidak sesuai dengan hasil penelitian yang dilakukan oleh, (Hooi et al., 2015), dan (Habib et al., 2012) yang menyatakan bahwa debt policy berpengaruh positif terhadap share price volatility.Kebijakan hutang menggambarkan keputusan kebijakan yang diambil oleh manajemen perusahaan dalam memperoleh sumber dana pembiayaan bagi perusahaan sehingga dapat mengoptimalkan kegiatan aktivitas operasional perusahaan. Hasil dari pengujian hipotesis ketiga ini tidak sesuai dengan hipotesis yang diajukan diawal penelitian ini.Penyebab tidak berpengaruhnya kebijakan hutang terhadap share price volatility disebabkan karena biaya operasional perusahaan bergantung terhadap hutang dan perusahaan mempunyai liabilitas untuk membayar bunga hutang yang menyebabkan keuntungan perusahaan berkurang. Namun, pengaruh yang dihasilkan tidak signifikan terhadap share price volatility karena hutang yang didapatkan dikelola dengan baik dan digunakan untuk meningkatkan kinerja perusahaan sesuai dengan strategi perusahan dan investor juga memandang perusahaan yang memiliki hutang yang tinggi lebih berusaha melakukan peningkatan laba. Dengan demikian, investor akan menahan kepemilikannya sehingga harga saham akan stabil. 
Hipotesis keempat yang diajukan dalam penelitian ini adalah growth asset berpengaruh negatif terhadapshare price volatility. Berdasarkan kesimpulan pengujian hipotesis pada Tabel 5, menunjukkan bahwa nilai standardized coefficient sebesar 2921.109 yang berarti menghasilkan arah yang positif dan nilai probabilitas sebesar 0.4234 yang lebih besar dari tingkat signifikansi $\alpha=0.05$ sehingga dapat disimpulkan bahwagrowth asset tidak berpengaruh terhadap share price volatility dan artinya hipotesis keempat ditolak.Hasil uji hipotesis ini sesuai dengan penelitian (Hooi et al., 2015) dan tidak sesuai dengan hasil penelitian yang dilakukan oleh (Jahfeer et al., 2016), (Shah dan Noreen, 2016), (Habib et al., 2012), dan (Sadiq et al., 2013) yang menyatakan bahwa growth asset berpengaruh negatif terhadap share price volatility. Growth Asset merupakan pertumbuhan sumber daya atau aset yang diprediksi akan membawa keuntungan manfaat ekonomi di masa yang akan datang. Hasil dari pengujian hipotesis keempat ini tidak sesuai dengan hipotesis yang diajukan diawal penelitian ini.

Penyebab tidak berpengaruhnya growth asset terhadap share price volatility disebabkan karena umumnya para investor tidak memanfaatkan informasi growth asset perusahaan. Besarnya aset yang dimiliki oleh perusahaan dapat menjadi salah satu jaminan bagi investor dalam berinvestasi di suatu perusahaan, namun growth asset tidak selalu menggambarkan baiknya arus keuangan perusahaan di perusahaan tersebut. Adanya kemungkinan pertumbuhan aset dimodali atau dibiayai oleh hutang yang besar akan menjadi pertimbangan kembali bagi investor dalam berfokus pada faktor lainnya dibandingkan dengan growth asset, sehingga informasi mengenai pertumbuhan aset tidak serta merta membuat para investor maupun calon investor segera melepas atau membeli saham perusahaan, maka mengakibatkan volatilitas harga saham di bursa cenderung stabil dan tidak berpengaruh terhadap volatilitas harga saham

Hipotesis yang kelima diajukan dalam penelitian ini adalah earning per shareberpengaruh negatif terhadapshare price volatility.Berdasarkan kesimpulan hasil pengujian hipotesis pada Tabel 10, menunjukkan bahwa nilai standardized coefficient sebesar -0.261955 yang berarti menghasilkan arah yang negatif dan nilai probabilitas sebesar 0.0316 yang lebih kecil dari tingkat signifikansi $\alpha=0.05$ sehingga dapat disimpulkan bahwa earning per share berpengaruh negatif signifikan terhadap share price volatility dan artinya hipotesis kelimaditerima.Hasil uji hipotesis ini sesuai dengan penelitian (Wickramasinghe, 2016) dan tidak sesuai dengan hasil penelitian yang dilakukan oleh (Shah and Noreen, 2016) yang menyatakan bahwa earning per share berpengaruh positif terhadap share price volatility.Earning per share merupakan laba bersih yang dihasilkan oleh perusahaan sebagai bentuk pengembalian kepada investor berupa keuntungan atas setiap dana yang diinvestasikan oleh para investor dan untuk para investor.

Penyebab berpengaruhnya earning per share terhadap share price volatility disebabkan karena tingkat earnings per share yang tinggi akan memberikan dorongan kepada investor untuk bertahan karena earning per share menunjuk keuntungan yang didapatkan oleh para investor saat menahan sahamnya di suatu perusahaan. Dengan tawaran tingkat earning per share yang terus meningkat akan mendorong stabilnya harga saham perusahaan karena peningkatannya tidak akan fluktuatif. Dengan keadaan tersebut maka semakin tinggi earning per share akan menurunkan fluktuasi pada harga saham. 


\section{PENUTUP}

Berdasarkan hasil pengujian data dalam penelitian ini, share price volatility tidak dipengaruhi oleh kebijakan dividen, earning volatility, kebijakan hutang dan growth asset, tetapi dipengaruhi oleh EPS.Keterbatasan pada penelitian ini adalah sebagai berikut: (a) Variabel yang terdapat pada penelitian ini terbatas pada lima variabel independen yaitu kebijakan dividen(DY), earning volatility(EV), kebijakan hutang(DEBT), growth asset (GA), dan earning per share (EPS) yang menyebabkan kurangnya luas ruang lingkup penelitian sehingga menyebabkan faktor-faktor lainnya yang dapat mempengaruhi share price volatilitytidak dipertimbangkan, (b) Obyek yang dipakai dalam penelitian ini hanya menggunakan sektor manufaktur sehingga penelitian ini tidak cukup mewakili seluruh sektor perusahaan yang terdaftar di Bursa Efek Indonesia (BEI), (c) Rentang penelitian hanya terbatas dari tahun 2015, 2016 dan 2017 sehingga tidak tedapat menggambarkan kondisi perusahaan yang sebenarnya dalam jangka panjang.

Saran yang dapat diberikan untuk penelitian selanjutnya adalah sebagai berikut: (a) Penelitian selanjutnya diharapkan dapat menambah variabel-variabel penelitian yang juga dapat mempengaruhi share price volatility contohnya variabel size, likuiditas sehingga cakupan yang diteliti juga menjadi luas, (b) Pada penelitian berikutnya diharapkan agar menambah jumlah sektor industri yang lain yang digunakan dalam subyek penelitian sehingga hasil penelitian yang didapat bisa mencerminkan semua sektor perusahaan yang terdaftar di Bursa Efek Indonesia (BEI), (c) Penelitian selanjutnya diharapkan agar dapat menambah jumlah tahun penelitian menjadi lebih dari tiga tahun sehingga dapat menghasilkan hasil penelitian yang lebih mencerminkan kondisi perusahaan yang sesungguhnya dalam jangka panjang

\section{DAFTAR RUJUKAN}

Ajija, S. R., dkk. (2011). Cara Cerdas Menguasai Eviews. Salemba Empat: Jakarta.

Anthony, N. Robert dan Govindarajan, Vijay. (2011). Sistem Pengendalian Manajemen. Jilid 2. Tanggerang: Karisma Publishing Group.

Brigham, Eugene F. dan Houston, Joel F. (2011). Dasar-dasar Manajemen Keuangan Terjemahan.Edisi 10. Jakarta:Salemba Empat.

Habib, Kiani, \& Khan (2012). Dividend Policy and Share Price Volatility: Evidence from Pakistan. Global Journal of Management and Business Research, 12(5)

Harmono.(2011). Manajemen Keuangan Berbasis Balanced Scorecard Pendekatan Teori, Kasus, dan Riset Bisnis (Edisi 1). Jakarta:Bumi Aksara.

Hestinoviana, Suhadak dan Handayani S.R. (2013). The Influence of Profitability, Solvability, Asset Growth and Sales Growth Toward Firm Value (Empirical Study on Mining Companies Which Listed on Indonesia Stock Exchange). Brawijaya Journal of Financial, 1.

Hooi, Albaity dan Ibrahimy.(2015). Dividen Policy and Share Price Volatility.Investment Management and Financial Innovations, 12.

Hussainey, Khaled, Mgbame, Chijoke Oscar, Chijoke-Mgbame, Aruoriwo M. (2011). Dividend Policy and Share Price Volatility: UK Evidence, The Journal of Risk Finance, 12(1).

Ilaboya, O. J dan M. Aggreh.(2013). Dividend Policy and Share Price Volatility.J. Asian Dev.Stud, 2(2). 
Jahfer dan Hameed. (2016). Dividend Policy and Share Price Volatility: Evidence From Colombo Stock Market. International Journal of Managerial and Financial Accounting, 8(2)

Jensen, Michael C., dan Meckling, William H. (1976). Theory of the firm : Managerial Behavior, Agency Costs and Ownership Structure. Journal of Financial Economics. Vol. 3 No.4.305-360.

Kasmir.(2012). Analisis Laporan Keuangan.Jakarta : PT Raja Grafindo Persada.

Khurniaji, Andreas Widhi \& Surya Raharja. (2013). Hubungan Kebijakan Dividen (Dividend Payout Ratio dan Dividend Yield) terhadap Volatilitas Harga Saham di Perusahaan- perushaaan yang Terdaftar di Bursa Efek Indonesia.Diponegoro Journal of Accounting. Vol. 2, No. 3.

Kyle A, Profilet dan Frank W, Bacon. (2013). Dividend Policy and Stock Price Volatility in The U.S Equity Capital Market. Proceedings of ASBBS, 20(1).

Nasution, Yenni Samri Juliati. (2015). Hypothesis Pasar Efisien/ Efficient Market Hypothesis.Jurnal Perspektif Ekonomi Darussalam, 1(1).

Ngoc, Dinh Bao dan Cuong, Nguyen chi. (2016).Impacts of Cash Dividend Policy on Stock Price Volatility.Proceedings of $11^{\text {th }}$ Annual London Business Research Conference.Imperial College, London, UK.

Reilly, Frank K dan Brown, Keith C. (2012). Investment Analysis and Portfolio Management, Tenth Edition. USA : South Western Cengage Learning.

Retnowati, Eka. (2013). Penyebab Underpricing Pada Penawaran Saham Perdana di Indonesia.Accounting Analysis Journal.Fakultas Ekonomi Universitas Negeri Semarang.

Riyanto, Bambang. (2011) Dasar-Dasar Pembelanjaan Perusahaan. Yogyakarta: BPFE.

Sadiq, Ahmad, Anjum, dan Rehman. (2013). Stock Price Volatility in Relation to Dividend Policy : A Case Study of Karachi Stock Market. Middle-East Journal of Scientific Research.1(1).

Shah \& Noreen (2016). Stock Price Volatility and Role of Dividend Policy: Empirical Evidence from Pakistan. International Journal of Economics and Financial Issues, $6(2)$.

Stephen, Gregory dan Maurice. (2015). Effect of Dividend on Share Price Volatility in Frontier Exchanges : Kenya's Perspective. Research Journal of Finance and Accounting, 6.

Sugiyono. (2014). Metode Penelitian Kuantitatif, Kualitatif, dan R\&D. Bandung : Alfabeta.

Theresia, Priskilla \& Arilyn, Erika Jimena (2015). Pengaruh Dividen, Ukuran Perusahaan, Hutang Jangka Panjang, Earning Volatility, Pertumbuhan Aset, Trading Volume, dan Volatilitas Harga Saham. Jurnal Bisnis dan Akuntansi, 17(2).

Wickamasinghe (2016).Earnings Fluctuation on Share Price Volatility.Earnings Fluctuation on Share Price Volatility. Journal of International Financial Management \& Accounting, 1. 